\title{
WAS wt Allele
}

National Cancer Institute

\section{Source}

National Cancer Institute. WAS wt Allele. NCI Thesaurus. Code C52261.

Human WAS wild-type allele is located within Xp11.4-p11.21 and is approximately $8 \mathrm{~kb}$ in length. This allele, which encodes Wiskott-Aldrich syndrome protein, plays a role in actin cytoskeletal organization. Mutations in this gene are the cause of Wiskott-Aldrich syndrome an X-linked disease characterized by eczema, immune deficiencies and thrombocytopenia. 